\title{
Zpráva z 2. kongresu International Society for Vascular Surgery
}

Ve dnech 14. až 16. února 2013 jsem se aktivně zúčastnil kongresu International Society for Vascular Surgery (ISVS) v Miami, USA se sdělením Quality-of-life assessement in patients after endovenous laser therapy and conventional surgery for great saphenous varicose veins. Kongresu jsem se mohl zúčastnit díky cestovnímu grantu České společnosti kardiovaskulární chirurgie (ČSKVCH) pro cévní chirurgy a kardiochirurgy do 35 let, kteří mají aktivní účast na některém ze zahraničních odborných kongresů.

Celý kongres byl rozdělen do několika neparalelních sekcí (onemocnění krkavic, onemocnění tepen dolních končetin, křečové žíly a kongestivní syndromy, pokroky v endovaskulární léčbě aneurysmat, hrudní aorta, multidisciplinární přístup v cévní chirurgii, hluboká žilní trombóza, chronická žilní insuficience, různé), v předsednictvu jednotlivých sekcí byli například Peter Gloviczki, Cees Wittens, Frank Veith, Alun Davies a další významné osobnosti současné světové angiochirurgie.
Hlavními organizátory celé akce byli již tradičně prof. Michel S. Makaroun z Pittsburghu a prof. Cees Wittens z Maastrichtu.

Kongres považuji za prínosnou a prakticky orientovanou akci s neocenitelnou možností osobního setkání s angiochirurgy, intervenčními radiology a s dalšími specialisty z rưzných zemí, umožňujicí sdílení zkušeností a srovnání úrovně péče o cévněchirurgické pacienty v různých regionech.

Tímto bych rád ještě jednou poděkoval České společnosti kardiovaskulární chirurgie za udělení cestovního grantu, s jehož pomocí jsem se kongresu mohl zúčastnit.

MUDr. Robert Vlachovský, Ph.D., II. chirurgická klinika, Lékařská fakulta Masarykovy univerzity a Fakultní nemocnice u sv. Anny v Brně, e-mail: robert.vlachovsky@fnusa.cz 